Prace Literackie LVIII

Wrocław 2018

https://doi.org/10.19195/0079-4767.58.15

MONIKA WISZNIOWSKA

ORCID: 0000-0002-3018-0466

Uniwersytet Śląski w Katowicach

\title{
Demitologizacja polskiej historii w reportażach literackich Pawła Smoleńskiego
}

W ubiegłym roku na naszym rynku wydawniczym pojawiła się, już pośmiertnie wydana, książka Zygmunta Baumana pod tytułem Retrotopia. Jak rządzi nami przeszłość ${ }^{1}$. Praca ta, w której socjolog rozważa znaczenie i konsekwencje konserwatywnego zwrotu, dostrzeganego przez niego we współczesnych społeczeństwach, zwróciła moją uwagę na interesujące zjawisko. Chodzi o powrót do kontekstu wspólnotowego, mocno opartego na wartościach, których poszukujemy nie jak dotąd w przyszłości, lecz przeszłości. Tytułowa retrotopia to według Baumana odmiana utopii, tyle że z obróconym wektorem z przyszłości na przeszłość. Jest szukaniem nadziei na lepsze życie, na naprawę tego, co nas dręczy, w tym, co minione. Jest więc rodzajem tęsknoty, idealizowania i tym samym mityzowania naszej przeszłości. Dodatkowo „powrót do łona” — jak pisze Bauman — jest także mocno związany z ,powrotem do plemion”, czyli produkowania wizji jasno określonej wspólnoty przeciwstawionej chaosowi nowoczesnego świata. Uciekamy więc w przeszłość w nadziei, że w niej znajdziemy receptę na bolączki współczesności świata, a szukamy jej w podzielanych mitach, konstruując wspólną pamięć ${ }^{2}$.

Wydaje się, że spostrzeżenia socjologa w dużej mierze wskazują na przyczyny kształtowania się współczesnej polityki historycznej czy konstruowania zbiorowej pamięci opartej — jak pisze Robert Traba — na ,jedn[ej] homogeniczn[ej] pamię[ci] »wszystkich Polaków«, definiowanych jako monolityczny naród”3. Tym samym stoimy — by kontynuować myśl historyka — w obliczu niebezpieczeństwa polegającego na uproszeniu opowieści o historii Polski ${ }^{4}$. Niebezpieczeństwo to dostrzegają nie tylko historycy, lecz także badacze pamięci, którzy pisali — tu

${ }^{1}$ Z. Bauman, Retrotopia. Jak rządzi nami przeszłość, przeł. K. Lebek, Warszawa 2018.

2 Zob. ibidem.

${ }^{3}$ R. Traba, Przeszłość w teraźniejszości. Polskie spory o historię na początku XXI wieku, Poznań 2009 , s. 77.

${ }^{4}$ Ibidem, s. 79. 
przytoczę słowa jednego z prekursorów Memory Studies Pierre’a Nory — o „determinacji, by uniknać ryzyka celebracji, [...], by zobiektywizować system historii narodowej i zdekomponować jej elementy"s.

\section{„Historycy bez patentu”}

Zadajmy więc pytanie - co wspólnego ze wspomnianymi badaniami historyków czy obserwacjami badaczy nad pamięcią kulturową mają polskie reportaże? Otóż wbrew pozorom bardzo wiele, zwłaszcza gdy mowa o książkach takich autorów, jak Małgorzata Szejnert, Cezary Łazarewicz, Włodzimierz Nowak czy Paweł Smoleński. Wymienieni tu reportażyści zajmują się naszą mniej lub bardziej odległą historią, odkrywają to, co często zepchnięte było w społeczne zapomnienie, stanowiło rodzaj pamięci - jak trafnie określa ją Jacek Żakowski — przemilczanej czy raczej uciszonej ${ }^{6}$. Oczywiście po roku 1989 powstało i powstaje nadal wiele naukowych publikacji, które walnie przyczyniają się do rewizji pamięci zbiorowej, ale wydaje się, iż akurat reportaże ze względu na swoją specyfikę gatunkową są po prostu chętniej czytane. Dlaczego tak się dzieje? Po pierwsze, reporterzy, o których tu wspomniałam, dokładają wszelkich starań, by stać się znawcami tematów, o których piszą. Ich wiedza jest nierzadko imponująca, o czym czytelnik może się przekonać, choćby zaglądając do zamieszczanych na końcu poszczególnych książek bibliografii. Po drugie, reportażowość jest taką konwencją literacką, której istota polega nie na opisie czy sprawozdaniu, lecz próbie zrozumienia i wyjaśnienia czytelnikowi procesów w tym świecie zachodzących, a tego przede wszystkim czytelnicy od reportera oczekują. Po trzecie, w reportażach odnajdujemy „wielką historię", ale przede wszystkim konkretne dramaty jednostkowe. A co najbardziej interesuje ludzi — inni ludzie. Jak trafnie konstatuje Maria Delaperrière, przyglądając się współczesnej literaturze świadectw:

Nie chodzi [...] o budowanie intrygi narracyjnej mającej na celu rekonstrukcję przeszłości, jak to się działo w tradycyjnycah powieściach historycznych, ale o przeżycie jej na nowo dzięki przywołaniu wrażeń, migawkowych obrazów lub fragmentów urywanych konwersacji zachowanych w pamięci indywidualnej ${ }^{7}$.

I ostatnia przyczyna - autorzy współczesnych reportaży literackich dobrze piszą, snują barwnym językiem opowieści o świecie — reportaż więc po prostu dobrze się czyta.

${ }^{5}$ P. Nora, The Era of Commemoration, [w:] Realms of Memory: The Construction of the French Past, t. 3. Symbols, red. P. Nora, New York 1998, s. 609, cyt. za: M. Saryusz-Wolska, Zapomnieć się w pamięci. Pytania o badanie pamięci kulturowej, Warszawa 2010, s. 85.

${ }^{6}$ Por. J. Żakowski, Rewanż pamięci, Warszawa 2002, s. 15-16.

${ }^{7}$ M. Delaperrière, Pod znakiem antynomii. Studia i szkice o polskiej literaturze XX wieku, Kraków 2006, s. 110. 
Być może twierdzeniem nieco na wyrost jest konstatacja, że reportaż literacki jest równorzędnym wobec akademickiej historiografii środkiem refleksji o historii i przeszłości, ale bez najmniejszej wątpliwości można powiedzieć, że jest jej wartościowym i interesującym suplementem. Nie bez przyczyny Marcin Kula historyk właśnie — widział reportaż historyczny jako ważny sposób uprawiania refleksji nad przeszłością, a reporterów mianował historykami bez patentu ${ }^{8}$.

Stawiam tezę, że reportaże wspomnianych autorów pełną dziś bardzo ważną funkcję polegającą na tworzeniu wyrw, szczelin w coraz częściej uładzonej i traktowanej jako jednolity konglomerat historii, sankcjonującej narodową homogeniczność, wyobrażonej jako jednorodna i dzięki temu dająca poczucie bezpieczeństwa. Dokonują tego, zwracając się ku przeszłości przemilczanej, przywracając konkurencyjną „pamięć innych”. Wyprowadzają nas tym samym ze swoistej strefy komfortu, demitologizując przeszłość, przywołując to, co mąci poczucie wspaniałości i jedności.

Paweł Smoleński jest reporterem i publicystą. Współpracował z pismami drugiego obiegu, między innymi paryską „Kulturą”, publikując pod pseudonimem Tomasz Jerz. Od 1989 roku jest dziennikarzem „Gazety Wyborczej”. W swoim bogatym dorobku ma książki opowiadające o Stanach Zjednoczonych, Izraelu, Iraku i Kurdach. Polsce poświęcił sześć pozycji, z czego trzy wydają mi się najbardziej reprezentatywne, jeśli chodzi o demitologizowanie polskiej historii: Pochówek dla rezuna ${ }^{9}$ — książka o relacjach polsko-ukraińskich, za którą w 2003 roku otrzymał nagrodę Pojednania Polsko-Ukraińskiego; Syrop z piołu$n u^{10}$, w której powraca do tematyki tużpowojennych dziejów wschodniego pogranicza oraz działań podjętych przez stronę polską w ramach tak zwanej akcji „Wisła”; oraz Krzyżyk niespodziany ${ }^{11}$ — książka napisana wspólnie z Bartłomiejem Kurasiem, przybliżająca nieznaną, myślę, znacznej części społeczeństwa niechlubną kartę historii górali tatrzańskich, czyli Komitetu Góralskiego zwanego Goralenvolkiem.

To nie są zagadnienia nieopracowane przez badaczy naszej najnowszej historii. Akademicy napisali wiele naukowych dysertacji na wspomniane tematy, warto jednak podkreślić, że jest to historia ciągle żywa, taka, która nie pozostawia

${ }^{8}$ Historyk bez patentu. Z Małgorzatą Szejnert rozmawia Daniel Lis, „Znak” 2011, nr 12. Zob. także M. Kula, Reportaż historyczny jako rodzaj wspótczesnej historiografii, [w:] Historia w kulturze współczesnej. Niekonwencjonalne podejścia do przeszłości, red. P. Witek, M. Mazur, E. Solska, Lubin 2011.

${ }^{9}$ P. Smoleński, Pochówek dla rezuna, Wołowiec 2011 [na oznaczenie tego wydania w dalszej części tekstu będę używała skrótu PR ze wskazaniem odpowiedniego numeru strony].

${ }^{10}$ P. Smoleński, Syrop z piołunu. Wygnani z akcji ,Wista”, Wołowiec 2017 [na oznaczenie tego wydania w dalszej części tekstu będę używała skrótu SP ze wskazaniem odpowiedniego numeru strony].

${ }^{11}$ B. Kuraś, P. Smoleński, Krzyżyk niespodziany. Czas Goralenvolk, Wołowiec 2017 [na oznaczenie tego wydania w dalszej części tekstu będę używała skrótu KN ze wskazaniem odpowiedniego numeru strony]. 
obojętnym, przy której poznawaniu ciągle możemy się zdziwić. Tak rolę reportera widzi Paweł Smoleński - iść tropem zdziwienia. „Jeśli nie ma [...] zdziwienia, to nie ma co pisać" - deklarował w jednym z wywiadów autor Syropu z piołu$n u^{12}$. Poznawanie historii nie jest więc dla reportera celem samym w sobie (co zazwyczaj dotyczy historyków), chodzi o inny punkt widzenia, o demitologizację — jak w wypadku tekstów Smoleńskiego, o rewizję i rewaloryzację historii, a tym samym także o podtrzymywanie ,żywej pamięci”.

Już po samych tytułach tych książek nietrudno się zorientować, że Smoleński dekonstruuje dwa ważne mity tworzące część składową oficjalnej polityki historycznej. Mit pierwszy: w relacjach polsko-ukraińskich to Polacy są stroną pokrzywdzoną. W świadomości społecznej minionych pięćdziesięciu lat istniały i rzeź wołyńska, i UPA, a nie przebijały się informacje o akcji „Wisła” czy historie o tym, jak Polacy krzywdzili Ukraińców. Potwierdza to Grzegorz Motyka, który wyraźnie wskazuje, że wbrew opinii rozpowszechnianej przez środowiska kresowe w polskim społeczeństwie wiedza o zbrodni wołyńskiej jest niezwykle duża ${ }^{13}$, o akcji zaś „Wisła” znikoma. Natomiast mit drugi to narracja o tym, że Polacy byli narodem niezłomnym, którzy podczas drugiej wojny światowej nie skalali się kolaboracją z okupantem. Warto tu przytoczyć słowa Anthony’ego Giddensa, który tak pisał o mitologizowaniu przeszłości:

Większość narodów odwołuje się do mitów historycznych, one zaś opierają się nie na przeszłości, a na rekonstrukcji owej przeszłości [...]. Narody zazwyczaj kształtują swe poczucie tożsamości, koncentrując się na jednych sprawach i pomijając inne ${ }^{14}$.

Właśnie owe „miejsca pominięte” zapełnia swoimi opowieściami Paweł Smoleński, opowiadając historię w poprzek oficjalnej wersji, dokładając ważną kartę do jej rewizji. Istotne jest jednak nie tylko to, że przypomina to, co „zapomniane", ważny jest też sposób, w jaki autor opowiada tę naszą trudną historię.

\section{Pochówek dla rezuna, czyli o polsko-ukraińskim węźle gordyjskim}

W Pochówku dla rezuna Smoleński zabiera czytelnika do Pawłokomy, Zawadki Morochowskiej i innych wiosek, w których krwawy kołowrót „śmierć za śmierć" nakręcał się przez wiele lat. Czytamy w jednym z reportaży:

${ }^{12}$ Pan Bóg lubi, gdy ludzie rozmawiają. Z Pawłem Smoleńskim rozmawia Agnieszka Wójcińska, [w:] A. Wójcińska, Reporterzy bez fikcji, Wołowiec 2011, s. 256.

13 Por. G. Motyka, Od rzezi wotyńskiej do akcji Wisła. Konflikt polsko-ukraiński 1943-1947, Kraków 2011.

${ }^{14}$ Historia i jej rekonstrukcje. Z Anthonym Giddensem rozmawia Teresa Stylińska, „Tygodnik Powszechny” 2006, nr 46 (dod. „Historia w Tygodniku”). 
Na pogórzu nastały straszne czasy. Jeśli w poniedziałek polskie wojsko spaliło ukraińską wieś, we wtorek i środę UPA puszczała z dymem polską, w czwartek palili Polacy, w piątek — Ukraińcy. Nakręcał się krwawy, fanatyczny kołowrót, śmierć za śmierć. (PR, s. 109)

To fragment, w którym autor w lapidarny sposób przywołuje historię pisaną przez wielkie „H”, ale demitologizacja odbywa się przede wszystkim na innym poziomie. Smoleński podobnie jak wielu innych autorów reportaży opowieść o ważnych wydarzeniach naszej historii układa $\mathrm{z}$ wielu historii prywatnych, jakby powiedziała Ewa Domańska - z „mikrohistorii” ${ }^{15}$. To historie ludzi, których biografie nie pasują, nie mieszczą się w ramy jednowymiarowej opowieści, tworzą podstawową materię całej książki. Gwoli przykładu przytoczmy opowieść kobiety bezskutecznie starającej się o pochówek męża Ukraińca, który zginął w czterdziestym pierwszym roku pod przemyską wsią Bircza. Czytamy w tytułowym reportażu:

Anna Karwańska jeździła do Polski z nadzieją, że pięćdziesiąt lat to czas wystarczający, by się „zmieniło", niestety okazało się, że od trudnej historii, od polityki, od niewygasłych po latach emocji nie można nigdy uciec, nawet wyjeżdżając na drugi koniec świata. (PR, s. 25)

Hanna Krall w jednym z wywiadów mówiła o bohaterach swoich książek:

Chciałabym, aby moi czytelnicy wyobrazili sobie tamtych ludzi — nie tylko ich śmierć, lecz ich życie. Chciałabym, żeby im było przykro, bo już nie ma tamtej cywilizacji, żeby było im żal, żeby zatęsknili za tamtym światem ${ }^{16}$.

Emocje we współczesnym reportażu są niezbywalną komponentą lektury. Ten „,idiom emocjonalny" 17 zarówno w tekstach Krall, jak i Smoleńskiego możemy dostrzec w zabiegach kompozycyjnych, w nacechowanym uczuciowo doborze faktów, jak też w nacechowanym aksjologiczne języku. To dzięki niemu inność doświadczeń, które stają się udziałem bohaterów, rodzi u czytelnika pewnego rodzaju skupioną uważność, szacunek, wręcz empatię. A empatia w Pochówku dla rezuna dość równo się rozkłada między bohaterów polskich, łemkowskich czy ukraińskich. Jest ich w książce Smoleńskiego bardzo wielu, nie sposób byłoby ich tu wszystkich wymienić, ale wszyscy pamiętają i nadal rozpamiętują zadany im kiedyś ból, wszyscy do dziś cierpią z powodu wyrządzonych im dawniej krzywd i nienawidzą tych, których mimo upływu lat traktują jako swoje największe zagrożenie, swoich nieprzejednanych wrogów. Jak trafnie pisze Bernadetta Darska:

Smoleński nie ocenia, nie wskazuje karcąco palcem, nie sugeruje, która strona ma rację, a która powinna swoich przekonań się wyrzec. Wręcz przeciwnie — oddając głos i Polakom, i Ukraińcom, pokazuje ludzi nieszczęśliwych, złamanych doznanym i zadanym złem, zniszczonych zawiścią, otumanionych niechęcią do szukania porozumienia ${ }^{18}$.

15 Zob. E. Domańska, Mikrohistorie, Spotkania w międzyświatach, Poznań 2005.

16 Pierwszym obowiązkiem jest wiedzieć. Z H. Krall rozmawia M. Jentys, „Sycyna” 1997, nr 3.

${ }^{17}$ H. Gosk, Zamiast końca historii. Rozumienie i prezentacja procesu historycznego $w$ polskiej prozie XX i XXI wieku podejmujacej tematy wspótczesne, Warszawa 2005, s. 113.

${ }^{18}$ B. Darska, Zła pamięć, http://bernadettadarska.blog.onet.p1/2011/08/12/zla-pamiec-p-smolenski-pochowek-dla-rezuna/ [dostęp: 15.04.2015]. 
Reporter w Pochówku dla rezuna w pełni wykorzystuje wielogłosowość, wielość punktów widzenia ${ }^{19}$. Taki był - wydaje się — zamysł autorski, by w splątanym gąszczu ludzkich, często niezwykle dramatycznych losów ukazać, że w historii polsko-ukraińskiej nic nie jest proste, nie da się jej przykroić do czarno-białego schematu.

\section{Syrop z piołunu - czyli o ostatecznym rozwiązaniu}

Akcja „Wisła”, czyli komunistyczne wysiedlenia ukraińskiej mniejszości z lat 1947-1950, o której opowiada Smoleński w książce zatytułowanej Syrop z piołunu, to kolejna odsłona niesamowicie pogmatwanej polsko-ukraińskiej historii. Niestety, jak wskazuje autor, po niemal trzydziestu latach od powstania III RP o akcjach przesiedleńczych wciąż opowiada się za pomocą kalek myślowych rodem z głębokiej PRL, Łun w Bieszczadach i Ogniomistrza Kalenia.

Używając tej samej metody co w Pochówku dla rezuna, także i w opowieści o akcji „Wisła” Smoleński upomina się o tych, którzy zostali pokrzywdzeni. Podobnie jak w poprzedniej książce szuka krzywd jednostkowych (rozmawia z przesiedleńcami, dociera do każdego bohatera z osobna) i jako wnikliwy obserwator próbuje je naświetlić. Biografie ludzi przemawiają o wiele mocniej niż historyczna statystyka, choć akurat tej w książce Smoleńskiego nie brakuje. Dotyczy to szczególnie reportażu o Centralnym Obozie Pracy w Jaworznie, w którym w jednym z podobozów więziono Ukraińców. Smoleński szczegółowo opisuje warunki, w jakich przetrzymywani byli podejrzani o współpracę z UPA: przesłuchania według stalinowskiej szkoły stosowane na więzionych - uporczywe bicie, elektrowstrząsy czy sławetny „pal Andersa” (SP, s. 118), ale nie chce wcielać się w rolę prokuratora. Kiedy wspomina o nadzorcach, pisze: „Pies tańcował z ich nazwiskami. Nie warto pamiętać” (SP, s. 119). Napisałam, że w Syropie z piołunu Smoleński przywołuje dane liczbowe. To prawda, jest ich — inaczej niż w Pochówku dla rezuna — wiele, ale przy okazji opowieści o „obozie przejściowym dla podejrzanych Ukraińców" (SP, s. 22) zauważa, że kiedy mowa o ludzkim cierpieniu — statystyka jest zupełnie nieprzydatna. Pisze, jednocześnie demaskując sposób tworzenia polityki historycznej:

W Jaworznie zmarły — z głodu, bicia i chorób — sto sześćdziesiąt dwie osoby, co niektórzy historycy (domorośli, ale też z dyplomami uniwersytetów) uznali za przesłankę, że nie działo się tam wcale źle: raptem dwa procent zgonów, czyli mniej niż pośród pacjentów szpitali. (SP, s. 22)

Smoleński, chcąc nakreślić rozległą panoramę ludzkich losów, przypomina także polskich milicjantów i żołnierzy. Próbuje wskazać jakieś okoliczności łagodzące, jak choćby tę, że byli zindoktrynowani egzotyczną mieszaniną Sien-

19 Por. A. Mikołajczuk, Punkt(y) widzenia w reportażu. Od etymologii nazwy do tworzywa gatunku, [w:] Punkt widzenia w tekście i dyskursie, red. J. Bartmiński, S. Niebrzegowska-Bartmińska, R. Nycz, Lublin 2004, s. 117. 
kiewicza i komunizmu, a czasem po prostu „chcieli się wykazać” w walce z „faszystowskimi bandami”. Autor ich nie usprawiedliwia, wskazuje jednak na rolę literatury, która w odpowiedni sposób wykorzystana jest przecież ważnym czynnikiem mitotwórczym. Ponadto Smoleński ujawnia także moc sprawczą języka. Reporter pyta, co by się stało, gdyby na przykład słowo „bandy” zamienić na sformułowanie ,żołnierze walczący o wolność i niepodległość Ukrainy”. Tradycja niepodległościowa konotuje u polskiego czytelnika całkiem przecież inne wartości. Nie bez powodu przytacza również zdanie z tajnej notatki Państwowej Komisji Bezpieczeństwa, w której możemy przeczytać o „ostatecznym rozwiązaniu problemu ukraińskiego w Polsce" (SP, s. 20).

Podobnie jak w swojej poprzedniej książce Smoleński daleki jest od oceniania trudnej polsko-ukraińskiej historii, swoją rolę widzi raczej w przełamywaniu stereotypów wchodzących w skład wskazanych mitów. Natomiast w ocenie wysiedleń z 1947 roku nie stosuje żadnych półtonów i rzeczy nazywa po imieniu. Już we wstępie zamieszcza treść siódmego artykułu statutu Międzynarodowego Trybunału Wojskowego z Norymbergi, który deportacje lub przymusowe przemieszczanie ludzkości kwalifikuje jako „zbrodnię przeciwko ludzkości” (SP, s. 5) i tak ją też opisuje.

Wydaje się, że ze względu na obrany temat i na jego tak jednoznaczną ocenę w Syropie z piołunu Smoleński wykorzystuje bardzo bogaty materiał dokumentalny. Jest w książce wiele cytatów z dokumentów wojskowych tamtych lat, mamy listy pasterskie głów kościołów katolickiego i greckokatolickiego tamtych lat, wypowiedzi parlamentarzystów, listy i fragmenty tekstów naukowych. To już nie są jedynie opowieści bohaterów, tu Smoleński jest świadomy, że aby ukazać Polaków jako winnych takiej — przypomnijmy — zbrodni przeciwko ludzkości, trzeba wykorzystać inny rodzaj argumentów niż tylko współczucie dla pojedynczego losu.

\section{Krzyżyk niespodziany, czyli o tym, po co rozliczać „do samiuśkiego spodu”}

Podobnie rzecz się ma w kolejnej książce, którą Smoleński tym razem napisał wraz z Bartłomiejem Kurasiem — pisarzem i dziennikarzem specjalizującym się w tematyce Tatr i Podhala. W Krzyżyku niespodzianym konstruują oni opowieść o skomplikowanych losach mieszkańców tych terenów, których wciąż dzieli pamięć o bolesnej przeszłości regionu. Książka porusza problematykę góralskiej kolaboracji na Podhalu podczas drugiej wojny światowej. Podobnie jak w Syropie z piotunu, także w tej pozycji autorzy korzystają z ogromu dokumentów (między innymi z prac Wojciecha Szatkowskiego - wnuka jednej z głównych postaci Goralenvolku). Krzyżyk niespodziany jest właściwie autorską kompilacją tych dokumentów, narracja autorów jest w zasadzie jedynie spoiwem. 
Bartłomiej Kuraś i Paweł Smoleński pokazali inną stronę Podhala niż ta dotychczas przewijająca się $\mathrm{w}$ zbiorowej pamięci. W książce wprost odwołują się do mitu. W rozdziale Lud to po prostu genialny ukazują najważniejsze elementy żyjącej już od czasów romantycznych legendy górali podhalańskich. Czytelnik może przypomnieć sobie, skąd pochodzi legenda o Janosiku, co pisał o góralach Seweryn Goszczyński, co Stanisław Witkiewicz, Stefan Żeromski, Gustaw Le Bon czy Kazimierz Przerwa Tetmajer. Autorom wcale nie chodzi, jakby się mogło wydawać, o zderzenie wymowy tej legendy z niechlubnymi postawami górali w czasie okupacji. Wręcz przeciwnie, pokazują raczej, że ów zmitologizowany obraz górala został utkany z twórczej wyobraźni i z ówczesną rzeczywistością niewiele miał wspólnego. We wspomnianym rozdziale możemy przeczytać:

Zbójnicy nie wiedli życia szczęśliwych i wolnych dzieci natury, jak ich się później i dzisiaj przedstawia. Wieszano ich za kradzież kilku oscypków albo jagnięcia. Jeśli mimo to kradli, to zwykle z głodu. (KN, s. 26)

Demitologizacja przebiega więc w Krzyżyku niespodzianym na dwóch poziomach. Mamy demitologizację samej legendy, która tworzyła obraz górala prawdziwego, wolnego Polaka pielęgnującego rodzimą kulturę, człowieka wolnego i szlachetnego (KN, s. 17). Ale też autorzy odwołują się do mitu niezłomnego Polaka, co ciekawe, mit ten — jak pokazują — jest proweniencji PRL-owskiej. Piszą Smoleński i Kuraś:

Według władzy ludowej Polska miała być krajem, który nie splamił się kolaboracją z Niemcami, uległość wobec wroga nie pasowała do zwycięstwa nad III Rzeszą. (KN, s. 143)

Choć starają się pokazać najróżniejsze oblicza tej kolaboracji, wskazują szacunki dotyczące pobrań kenkart „G”, udziału w Komitecie Góralskim czy też rzeczywistą liczebność ochotników do Góralskiego Legionu Waffen SS, to nie odnajdzie czytelnik w Krzyżyku niespodzianym tonu oskarżycielskiego. Wręcz przeciwnie. Oprócz opowieści o Wacławie Krzeptowskim „góralskim księciu”, który widział górali ,pod skrzydłami wielkiego narodu niemieckiego” (KN, s. 44), a który w styczniu 1944 roku został aresztowany przez Armię Krajową i powieszony, oprócz objaśnienia roli innych, Szatkowskiego, Cukra, Wiedera czy pomniejszych działaczy Góralskiego Komitetu, autorzy nie zapominają o innym Krzeptowskim, Józefie, słynnym kurierze tatrzańskim, który „nosił na Węgry mikrofilmy, meldunki, papiery" (KN, s. 83), lecz także o innych odważnych kurierach, więźniach obozów koncentracyjnych, żołnierzach Konfederacji Tatrzańskiej czy o zwykłych góralach, ofiarach łapanek. Książka jest tak skomponowana, by potwierdzać tezę, którą autorzy konstruują pod koniec książki: „na obszarze świątecznego obrusa można było zobaczyć postawy skrajnie oportunistyczne i skrajnie heroiczne" (KN, s. 143).

Na koniec warto jeszcze zapytać, czemu ma służyć demitologizowanie historii nie tylko u Smoleńskiego, lecz także w innych polskich reportażach historycznych. Wydaje się, że reporterzy chcą mieć wpływ na przemeblowywanie pamięci zbiorowej i komunikatywnej, zależy im na tym, by ich książki stały się ważnym głosem 
w ustalanej przecież wciąż pamięci kulturowej. Chcą stanowić zaporę, barierę przez napierającym zewsząd myśleniem w kategoriach retrotopii. Co proponuje Smoleński - zamiast idealizowania, ujednolicania i tym samym mityzowania naszej przeszłości - rozumienie historii jako przestrzeni dialogu. Jego postawę możemy określić jako — tu posiłkuję się terminem Basila Kerskiego — samokrytyczny patriotyzm, rozumiany jako najbardziej patriotyczna postawa, patriotyczna w sensie troski o Rzeczpospolitą, o kondycję kultury demokratycznej narodu ${ }^{20}$.

Warto jeszcze dodać, że te książki to także dobra literatura, choćby dlatego że przekaz zawarty w książkach autora Pochówku dla rezuna ma także wymiar uniwersalny. Reportaże dotyczą historii, o historii opowiadają, ale w wymowie dotykają spraw naszej współczesności. Smoleński pisze książki rownież ku przestrodze.

W Krzyżyku niespodzianym autorzy, rekonstruując proces przemilczania, politycznego dyscyplinowania wspomnień oraz historycznych przekłamań, ukazują przede wszystkim, że cisza nikomu nie służy, że historia nierozliczona „do samiuśkiego spodu" (KN, s. 146) może zostać instrumentalnie użyta.

Pochówek dla rezuna to przecież opowieść także o tym, że jeżeli krzywd nie można wykrzyczeć, jeżeli pamięć się nie zmaterializuje, choćby w postaci prostego krzyża na grobie poległych, to świat małej ojczyzny staje się infernem zdominowanym — jak pisze Kapuściński we wstępie do książki Smoleńskiego — przez najgorszy typ nienawiści: etnonacjonalizm ${ }^{21}$.

Natomiast Syrop z piołunu to także niezwykle interesująca opowieść o PRL-owskiej propagandzie. W rozdziale Poszedt Karol (to opowieść o Karolu Świerczewskim) Smoleński opowiada czytelnikowi zdecydowanie zmodyfikowaną wersję opowieści $O$ człowieku, który się kulom nie kłaniat, a na jej kanwie autor przestrzega przed manipulacją faktami historycznymi, przed używaniem jej do celów politycznych. Chyba nie ma wątpliwości co do aktualności i jednocześnie przesłania zawartego $\mathrm{w}$ cytacie:

Jego losy [chodzi oczywiście o Karola Świerczewskiego - M.W.] to dowód, jak można z niczego, lekceważąc prawdę, napisać historię. Co tam historię! Można napisać teraźniejszość, która — choć działa się nieledwie wczoraj — zamienia się w legendę. (SP, s. 73)

\section{Bibliografia}

Bauman Z., Retrotopia. Jak rządzi nami przeszłość, przeł. K. Lebek, Warszawa 2018.

Darska B., Zła pamięć, http://bernadettadarska.blog.onet.pl/2011/08/12/zla-pamiec-p-smolenski-pochowek-dla-rezuna/ [dostęp: 15.04.1015].

Delaperrière M., Pod znakiem antynomii. Studia i szkice o polskiej literaturze XX wieku, Kraków 2006.

${ }^{20}$ Wieczna melodia życia. Z Basilem Kerskim rozmawia Agnieszka Drotkiewicz, „Dwutygodnik" 2010, nr 27, https://www.dwutygodnik.com/artykul/995-wieczna-melodia-zycia.html [dostęp: 12.11.2018].

${ }^{21}$ Por. R. Kapuściński, Zła pamięć, [w:] P. Smoleński, Pochówek dla rezuna, s. 6. 
Domańska E., Mikrohistorie, Spotkania w międzyświatach, wyd. 2 uzupełnione i uaktualnione, Poznań 2005.

Gosk H., Zamiast końca historii. Rozumienie i prezentacja procesu historycznego w polskiej prozie XX $i$ XXI wieku podejmującej tematy wspótczesne, Warszawa 2005.

Historia i jej rekonstrukcje. Z Anthonym Giddensem rozmawia Teresa Stylińska, „Tygodnik Powszechny” 2006, nr 46 (dod. „Historia w Tygodniku”).

Kula M., Reportaż historyczny jako rodzaj wspótczesnej historiografii, [w:] Historia w kulturze wspótczesnej. Niekonwencjonalne podejścia do przeszłości, red. P. Witek, M. Mazur, E. Solska, Lubin 2011.

Kuraś B., Smoleński P., Krzyżyk niespodziany. Czas Goralenvolk, Wołowiec 2017.

Mikołajczuk A., Punkt(y) widzenia w reportażu. Od etymologii nazwy do tworzywa gatunku, [w:] Punkt widzenia $w$ tekście $i$ dyskursie, red. J. Bartmiński, S. Niebrzegowska-Bartmińska, R. Nycz, Lublin 2004.

Motyka G., Od rzezi wotyńskiej do akcji Wista. Konflikt polsko-ukraiński 1943-1947, Kraków 2011.

Nora P., The Era of Commemoration, [w:] Realms of Memory: The Construction of the French Past, t. 3. Symbols, red. P. Nora, New York 1998.

Saryusz-Wolska M., Zapomnieć się w pamięci. Pytania o badanie pamięci kulturowej, Warszawa 2010.

Smoleński P., Pochówek dla rezuna, Wołowiec 2011.

Smoleński P., Syrop z piołunu. Wygnani z akcji ,Wisła”, Wołowiec 2017.

Traba R., Przeszłość w teraźniejszości. Polskie spory o historię na początku XXI wieku, Poznań 2009.

Wójcińska A., Reporterzy bez fikcji, Wołowiec 2011.

Żakowski J., Rewanż pamięci, Warszawa 2002.

\section{Demythologization of Polish history in the literary journalism of Paweł Smoleński}

\section{Summary}

Paweł Smoleński adds an important voice to the critical discussion about Polish history. In his books such as Pochówek dla rezuna, Syrop z piolunu. Wygnani w akcji ,Wisła” and Krzyżyk niespodziany. Czas Goralenvolk (written together with Bartłomiej Kuraś) the author reveals the dark side of incidents that occurred during the Second World War and soon after. With full consciousness of the stereotypes and tradition fixed in the Polish memory, shows his relation to the history of nation from, on the one hand, and excavates from it the essence that may and should lead to a better understanding of the present time, on the other. Using the biography of ordinary people, Smoleński, showing the full value of private, colloquial, sometimes internally discrepant voices, reconstructs the process of passing into silence, political control of reminiscences and historical falsehood. His books are stories written to warn.

First of all, it is very good literature with a universal message. Smoleński shows in a very interesting way the "human measure of history," helplessness of ordinary people in the face of politics and formal institutions, the easiness of controlling the reaction of masses and power of the language of propaganda. His books open the way for a better review of difficult past times but also, what is more important, help to better understand the present.

Keywords: Paweł Smoleński, literary journalism, history demythologized, cultural memory 